\title{
Evaluation of Stress and Burnout Levels of Healthcare Professionals Working in COVID-19 Services*
}

\author{
COVID-19 Servislerinde Görev Yapan Sağlık Çalışanlarının Stres ve Tükenmişlik Düzeylerinin \\ Değerlendirilmesi
}

\author{
Hatice Yağcı', Nuray Dayapoğlui, Ömer Karaşahin ${ }^{\mathrm{ii}}$
}

'Lecturer., Karamanoğlu Mehmetbey University, Ermene Uysal and Hasan Kalan Health Services Vocational School, Department of Medical Services and Techniques, First and Emergency Aid Program, https://orcid.org/0000-0002-9134-6036

iissoc.Prof., Atatürk University, Faculty of Nursing, Department of Nursing, https://orcid.org/0000-0003-2037-0060 iiiDr.,Erzurum City Hospital, Infectious Diseases Service, https://orcid.org/0000-0002-4245-1534 ABSTRACT

Objective: The COVID-19 pandemic started in Wuhan Province of China in December 2019 and has affected the whole world in a short time. During the pandemic period, healthcare professionals have to work at a very busy pace both with increased workload and at a risk of contamination. This study was conducted to evaluate the stress and burnout levels of healthcare professionals working in COVID-19 services.

Method: Maslach Burnout Inventory and Perceived Stress Scale were used as the data collection tools. The scores obtained from the scales were compared according to demographic characteristics such as gender, profession, marital status, having children, people lived together and presence of a chronic disease. SPSS packaged software was used for the analysis of data.

Results: It was found that while emotional burnout levels of the nurses were higher, the depersonalization levels of health technicians were lower. Emotional burnout and stress levels of the women were higher than those of men. It was seen that stress levels of those with a chronic disease were higher. Emotional burnout, depersonalization and stress levels of healthcare professionals who were tested for COVID-19 disease were higher. Personal accomplishment scores of those who were working voluntarily in COVID-19 services were higher.

Conclusion: It was concluded that the healthcare professionals with high stress and burnout levels had high levels of stress and burnout levels during COVID-19 Pandemic due to reasons such as the disease transmission risk and increased workload.

Keywords: COVID-19, Healthcare Professionals, Stress

öz

Amaç: COVID-19 pandemisi, Aralık 2019'da Çin'in Wuhan eyaletinde başlayarak kısa sürede tüm dünyayı etkisi altına almıştır. Pandemi süresince sağlık çalışanları, hem bulaş riski altında hem de artan iş yükü ile oldukça yoğun bir tempoda çalışmışlardır. Bu araştırma COVID-19 servislerinde görev yapan sağlık çalışanlarının stres ve tükenmişlik düzeylerini değerlendirmek amacıyla yapılmıştır.

Yöntem: Veri toplama araçları olarak Maslach Tükenmişlik Ölçeği ve Algılanan Stres Ölçeği kullanılmıştır. Ölçeklerden alınan puanlar cinsiyet, meslek, medeni durum, çocuk sahibi olma, birlikte yaşanılan kişiler ve kronik hastalık varlığı gibi demografik özelliklere göre karşılaştırılmıştır. Verilerin analizi için SPSS paket programı kullanılmıştır.

Bulgular: Hemşirelerin duygusal tükenme düzeyleri daha yüksek bulunurken, sağlık teknikerlerinin duyarsızlaşma düzeyleri daha düşük bulunmuştur. Kadınların duygusal tükenme ve stres düzeyleri erkeklere göre daha yüksek bulunmuştur. Kronik hastalığı olanların stres düzeylerinin daha yüksek olduğu görülmüştür. COVID-19 yönelik test yaptıran sağlık çalışanlarının duygusal tükenme, duyarsızlaşma ve stres düzeylerinin daha yüksek olduğu tespit edilmiştir. COVID-19 servislerinde kendi isteği ile çalışanların kişisel başarı puanları daha yüksek bulunmuştur.

Sonuç: Stres ve tükenmişlik düzeyleri yüksek olan sağıık çalışanlarının, hastalık bulaş riski ve artan iş yükü gibi sebeplerden dolayı COViD pandemisi süresince de stres ve tükenmişlik düzeylerinin yüksek olduğu sonucuna varılmıştır.

Anahtar Kelimeler: COVID-19, Sağlık çalışanı, Stres

${ }^{*}$ Lokman Hekim Dergisi, 2021; 11 (2): 381-390

DOI: $10.31020 /$ mutftd.896858

e-ISSN: 1309-8004, ISSN 1309-761X

Geliş Tarihi - Received: 15 Mart 2021; Kabul Tarihi - Accepted: 29 Nisan 2021

iletişim - Correspondence Author: Nuray Dayapoğlu <nuraydayapoglu@hotmail.com>

Ethical Approval: Ethics Committee of Ataturk University Faculty of Medicine (28.05.2020/B.30.2.ATA.0.01.00/292) 


\section{Introduction}

In December 2019, a cluster of pneumonia started to be seen in people in Wuhan province of China. The pathogen was designated as SARS-CoV-2 by the International Committee on Taxonomy of Viruses and this pneumonia was named as Coronavirus Disease 2019 (COVID-19) by the World Health Organization. ${ }^{1}$

Although the source of the infection is not known precisely, the common idea is that the host is wild animals that are illegally sold on the Wuhan seafood wholesale market. Although the first source is thought to be wild animals, the virus has been reported to transmit from human to human through contact and droplets. It can be transmitted through direct inhalation of respiratory secretions of infected people or indirectly by carrying the virus from a contaminated surface to the mouth and nose. ${ }^{2-3}$

While almost half of COVID-19 patients have the disease with very mild symptoms or asymptomatically, the other half mostly show symptoms such as fever, dry cough, dyspnoea, fatigue and myalgia. ${ }^{4-5}$

Healthcare professionals responsible for the treatment of patients during the COVID-19 pandemic are at serious risk. Physicians and nurses are at risk of infection while they perform the interventions like examining patients, taking samples from respiratory tract, monitoring vital signs, intubation, catheter, urinary catheter and vascular access. In addition, healthcare technicians applying imaging methods such as tomography / X-ray, cleaning staffs cleaning the patients' rooms, basins they use and carrying the samples taken, laboratory staff working on patients' samples, ambulance teams providing patient transfer, secretaries making patient records, security guards, and all other employees who perform guiding and other tasks in the pandemic hospitals are also at risk of getting the disease. ${ }^{6}$ The infection risk can be minimized by taking measures in hospitals such as proper use of protective equipment, minimization of invasive interventions, washing hands frequently, not touching face with hands, using alcohol-based hand disinfectants, proper disinfection of the equipment and surfaces used with alcohol or bleach, and ventilating the rooms frequently. ${ }^{7}$

Due to the patient density brought by the pandemic, the healthcare professionals perform their duties with more intense shifts and longer working hours. During this period, many healthcare professionals have to live separately from their homes and families. There are studies in literature showing that the stress and burnout levels of healthcare professionals are also high except for the pandemic period. ${ }^{8-13}$ It is believed that the pandemic period increased the workload, stress and burnout even more on the employees. This study was conducted to evaluate the stress and burnout levels of healthcare professionals working in COVID-19 services.

\section{Material Method}

\section{Type of the Study}

This is a descriptive and cross-sectional study.

\section{Location and Period of the Study}

The study was conducted in COVID-19 services, outpatient clinics and intensive care units in the HSU Erzurum Regional Training and Research Hospital. The data were collected between 29-31 May 2020 and the study was completed between 29 May and 30 June 2020.

\section{Sample Selection}

Considering the number of physicians (48), nurses (320), cleaning staff (90) and other healthcare professionals (tomography technicians (5), x-ray technicians (20), surveillance workers (15) in COVID-19 services, the population was found as 498 . Using the sample calculation formula with a known population, 
(by taking prevalence value as (p): 0.5 ), the sample size was calculated to be at least 218 people. Number of people participating in the present study was 300 and the participation rate in the study was $60.2 \%$.

\section{Data Collection}

The data were collected from the participants using a questionnaire through face-to-face interview technique. Personal information form prepared by the researchers, "Maslach Burnout Inventory" which was developed by Christina Maslach and Susan Jackson in 1986 and whose Turkish adaptation, validity and reliability study was conducted by Ergin in 1992 and "Perceived Stress Scale" which was developed by Kamarck and Mermelstein in 1983 and adapted to Turkish by Eskin et al., in 2013 were used as data

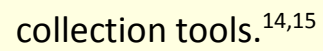

Although the original version of the Maslach Burnout Inventory consisting of 22 items is a 7-point Likert scale, the scale was adapted to a 5-point Likert type scale in the adaptation study conducted by Ergin considering that it was not suitable for Turkish culture. The questions are responded based on their severity as 1-Never, 2-Rarely, 3-Sometimes, 4-Mostly, 5-Always. Maslach Burnout Inventory is composed of 3 subscales; emotional burnout, depersonalization, and personal accomplishment. High scores taken from the emotional burnout and depersonalization subscales and low scores taken from the personal accomplishment subscale indicate that the employees are in a burnout state. In the Turkish adaptation study of the Maslach Burnout Inventory, Cronbach's alpha internal consistency coefficients were calculated as 0.83 for emotional burnout subscale, 0.65 for depersonalization subscale and 0.72 for personal accomplishment subscale.

Perceived Stress Scale consisting of 14 items is used to measure how stressful certain situations are perceived in a person's life. The participants rate the scale items by evaluating them as Never (0), Almost never (1), Sometimes (2), Quite often (3) and very often (4). A high score refers to a high stress perception of a person. In the Turkish adaptation study, Cronbach's Alpha internal consistency coefficient of the scale was calculated as 0.84 .

\section{Data Analysis}

The healthcare professionals providing care to COVID-19 infection patients are grouped as doctors, nurses, health technicians, and cleaning staff. Maslach burnout inventory and perceived stress scale scores applied to the healthcare professionals were calculated. The subscale scores of the scale were compared according to the demographic characteristics, willing follow-up of COVID-19 disease, and status of receiving training and testing status. Normality distribution for quantitative variables was tested with Kolmogorov-Smirnov test $(p>0.05)$. Chi-square test and Fisher's exact test were applied appropriately for categorical variables. Depending on the suitability condition, the continuous variables between two groups were compared with Student's t-test or Mann-Whitney $U$ test. In the comparison of more than one group, Kruskal Wallis Test was applied.

In the study, Cronbach's Alpha coefficient of the Maslach Burnout Inventory was calculated as 0.88 for emotional burnout subscale, 0.68 for the depersonalization subscale, and 0.74 for Personal accomplishment subscale. For the Perceived Stress Scale, the Cronbach's Alpha value was found as 0.60.

SPSS packaged software (SPSS 21.0 software, IBM-SPSS Inc, Chicago, IL) was used for the data analysis.

\section{Ethical Principles of the Study}

In order to conduct the study, official approvals were obtained from the Ethics Committee of Ataturk University Faculty of Medicine (28.05.2020/ B.30.2.ATA.0.01.00/292) and from the Ministry of Health COVID-19 Scientific Research Evaluation Commission (11.05.2020) and by getting the informed consents of 
the healthcare professionals, the questionnaire was applied only to those who were voluntary to participate in the study.

\section{Results}

The mean age of 300 healthcare professionals included in our study was $28.84 \pm 7,16$ and the median was 26 (20-57) and 175 of them (58.3\%) were female. Distribution of the healthcare professionals working in COVID-19 services as occupational group was found as 201 nurses (67.0\%), 40 cleaning staff (13.3\%), 31 healthcare technicians (10.3\%), and 28 physicians (9.3\%). 121 healthcare professionals (40.3\%) were married and $86(28.7 \%)$ had children. Of the healthcare professionals, 157 (52.3\%) were living with their families, 73 (24.3\%) were living alone, 46 (15.3\%) were living with roommates, and 24 (8.0\%) were living in a dormitory. $24(8.0 \%)$ of the healthcare workers had chronic diseases. Of the healthcare professionals working in services monitoring COVID-19 patients, 132 (44.0\%) were working voluntarily and 233 (77.7\%) stated that they received training about COVID-19 disease. 139 (39.3\%) of the healthcare professionals had RT-PCR test from respiratory tract samples for COVID-19 disease while they did not have any symptoms.

Table 1 represents evaluation of Maslach burnout inventory subscale scores among the occupational groups. According to occupational groups, no statistically significant difference was found between the cases' scores from the emotional burnout and depersonalization subscales of Maslach Burnout inventory ( $p=0.003$ and $p=0.002$, respectively) (Table 1 ). This difference that emerged in the emotional burnout subscale was caused by the statistically significantly higher scores of nurses compared to the healthcare technicians and cleaning staff $(p=0.001$ and $p=0.028$, respectively). No difference was found between the other occupational groups $(p>0.05$ ). The statistically significant difference determined between the scores obtained from the depersonalization subscale from the occupational groups was caused by the statistically significantly lower scores of the healthcare technicians compared to the doctors and nurses $(p=0.008$ and $p<0.001$, respectively). No statistically significant difference was determined between the cases' scores from the Personal accomplishment subscale of the Maslach Burnout scale according to the occupational groups $(p=0.058)$. No statistically significant difference was determined between the the perceived stress scale scores of the cases in terms of occupational groups $(p=0.293)$ (Table 1) (Kruskal Wallis Test was applied).

Table 1. Evaluation of Maslach burnout inventory subscale and perceived stress scale scores among the occupational groups

\begin{tabular}{|c|c|c|c|c|}
\hline & & Mean $\pm S D$ & Median (min- max) & $\mathrm{p}^{*}$ \\
\hline & Occupational Groups & & & \\
\hline \multirow[t]{4}{*}{ Emotional burnout } & Doctor & $23.07 \pm 8.19$ & $25.5(9-37)$ & 0.003 \\
\hline & Nurse & $25.10 \pm 7.93$ & $25(9-44)$ & \\
\hline & Healthcare technician & $20.03 \pm 7.86$ & $18(9-44)$ & \\
\hline & Cleaning staff & $22.10 \pm 6.79$ & $22.5(9-40)$ & \\
\hline \multirow[t]{4}{*}{ Depersonalization } & Doctor & $10.89 \pm 4.15$ & $11(5-19)$ & 0.002 \\
\hline & Nurse & $10.37 \pm 3.46$ & $10(5-22)$ & \\
\hline & Healthcare technician & $8.09 \pm 2.90$ & $7(5-16)$ & \\
\hline & Cleaning staff & $9.63 \pm 4.01$ & $9(5-21)$ & \\
\hline \multirow[t]{4}{*}{ Personal accomplishment } & Doctor & $27.21 \pm 5.29$ & $28(8-34)$ & 0.058 \\
\hline & Nurse & $28.45 \pm 4.13$ & $29(8-38)$ & \\
\hline & Healthcare technician & $30.51 \pm 5.14$ & $31(19-39)$ & \\
\hline & Cleaning staff & $29.80 \pm 5.58$ & $29.5(21-40)$ & \\
\hline \multirow[t]{4}{*}{ Perceived Stress Scale } & Doctor & $32.96 \pm 3.92$ & $33.5(22-41)$ & 0.293 \\
\hline & Nurse & $32.96 \pm 4.76$ & $33(18-53)$ & \\
\hline & Healthcare technician & $33.25 \pm 3.41$ & $34(27-39)$ & \\
\hline & Cleaning staff & $31.07 \pm 5.28$ & $32(16-42)$ & \\
\hline
\end{tabular}


Table 2 presents evaluation of the Maslach burnout inventory subscale and Perceived stress scale scores of the healthcare professionals according to their demographic characteristics. A statistically significant difference was determined between the cases' scores from the Emotional burnout subscale of the Maslach Burnout inventory according to gender. This difference is caused by the higher scores of women from the emotional burnout subscale compared to men $(p=0.041)$. Perceived stress scale scores were statistically significantly higher in women compared to men $(p<0.001)$. Healthcare professionals with a chronic disease had statistically significantly higher scores of perceived stress scale compared to those without any chronic disease ( $p=0.022$ ) (Table 2) (Mann-Whitney $U$ test and Kruskal Wallis test were applied).

Table 2. Evaluation of Maslach Burnout Inventory subscale and Perceived Stress Scale scores according to Demographic Characteristics

\begin{tabular}{|c|c|c|c|c|}
\hline & & Mean \pm SD & Median (min - max) & $\mathbf{P}^{*}$ \\
\hline & Gender & & & \\
\hline \multirow[t]{2}{*}{ Emotional burnout } & Female & $24.82 \pm 7.63$ & $25(11-44)$ & 0.041 \\
\hline & Male & $22.82 \pm 8.29$ & $23(9-44)$ & \\
\hline \multirow[t]{2}{*}{ Depersonalization } & Female & $10.08 \pm 3.39$ & $10(5-20)$ & 0.713 \\
\hline & Male & $10.09 \pm 3.92$ & $9(5-22)$ & \\
\hline \multirow[t]{2}{*}{ Personal accomplishment } & Female & $28.40 \pm 3.99$ & $29(18-37)$ & 0.121 \\
\hline & Male & $29.18 \pm 5.37$ & $29(8-40)$ & \\
\hline \multirow[t]{3}{*}{ Perceived Stress Scale } & Female & $33.51 \pm 3.80$ & $34(18-43)$ & $<0.001$ \\
\hline & Male & $31.65 \pm 5.50$ & $31(16-53)$ & \\
\hline & Marital Status & & & \\
\hline \multirow[t]{2}{*}{ Emotional burnout } & Married & $24.50 \pm 8.18$ & $25(9-44)$ & 0.240 \\
\hline & Single & $23.64 \pm 7.81$ & $23(9-44)$ & \\
\hline \multirow[t]{2}{*}{ Depersonalization } & Married & $10.09 \pm 3.74$ & $9(5-21)$ & 0.871 \\
\hline & Single & $10.08 \pm 3.54$ & $10(5-22)$ & \\
\hline \multirow[t]{2}{*}{ Personal accomplishment } & Married & $29.10 \pm 5.02$ & $29(8-40)$ & 0.285 \\
\hline & Single & $28.47 \pm 4.33$ & $29(8-38)$ & \\
\hline \multirow[t]{3}{*}{ Perceived Stress Scale } & Married & $33.12 \pm 4.76$ & $34(16-48)$ & 0.052 \\
\hline & Single & $32.48 \pm 4.60$ & $32(18-53)$ & \\
\hline & Presence of Children & & & \\
\hline \multirow[t]{2}{*}{ Emotional burnout } & Yes & $23.62 \pm 8.69$ & $24.5(9-43)$ & 0.771 \\
\hline & No & $24.13 \pm 7.66$ & $23(9-44)$ & \\
\hline \multirow[t]{2}{*}{ Depersonalization } & Yes & $9.74 \pm 3.96$ & $9(5-21)$ & 0.108 \\
\hline & No & $10.22 \pm 3.47$ & $10(5-22)$ & \\
\hline \multirow[t]{2}{*}{ Personal accomplishment } & Yes & $29.41 \pm 5.44$ & $29(8-40)$ & 0.111 \\
\hline & No & $28.45 \pm 4.23$ & $29(8-38)$ & \\
\hline \multirow[t]{3}{*}{ Perceived Stress Scale } & Yes & $32.91 \pm 4.89$ & $34(16-42)$ & 0.165 \\
\hline & No & $32.66 \pm 4.58$ & $33(18-53)$ & \\
\hline & People living with & & & \\
\hline \multirow{4}{*}{ Emotional burnout } & Alone & $23.07 \pm 8.19$ & $25.5(9-37)$ & 0.379 \\
\hline & Family & $25.10 \pm 7.93$ & $25(9-44)$ & \\
\hline & Roommate & $20.03 \pm 7.86$ & $18(9-44)$ & \\
\hline & Dormitory & $22.10 \pm 6.79$ & $22.5(9-40)$ & \\
\hline \multirow{4}{*}{ Depersonalization } & Alone & $10.89 \pm 4.15$ & $11(5-19)$ & 0.117 \\
\hline & Family & $10.37 \pm 3.46$ & $10(5-22)$ & \\
\hline & Roommate & $8.09 \pm 2.90$ & $7(5-16)$ & \\
\hline & Dormitory & $9.63 \pm 4.01$ & $9(5-21)$ & \\
\hline \multirow[t]{4}{*}{ Personal accomplishment } & Alone & $27.21 \pm 5.29$ & $28(8-34)$ & 0.696 \\
\hline & Family & $28.45 \pm 4.13$ & $29(8-38)$ & \\
\hline & Roommate & $30.51 \pm 5.14$ & $31(19-39)$ & \\
\hline & Dormitory & $29.80 \pm 5.58$ & $29.5(21-40)$ & \\
\hline \multirow[t]{5}{*}{ Perceived Stress Scale } & Alone & $33.09 \pm 3.65$ & $34(25-41)$ & 0.115 \\
\hline & Family & $32.87 \pm 4.70$ & $33(16-48)$ & \\
\hline & Roommate & $31.45 \pm 5.82$ & $31(18-53)$ & \\
\hline & Dormitory & $33.50 \pm 4.71$ & $33.5(20-43)$ & \\
\hline & $\begin{array}{l}\begin{array}{l}\text { Presence of a chronic } \\
\text { disease }\end{array} \\
\text { disen }\end{array}$ & & & \\
\hline \multirow[t]{2}{*}{ Emotional burnout } & Yes & $22.41 \pm 8.73$ & $21,5(12-41)$ & 0.221 \\
\hline & No & $24.12 \pm 7.89$ & $24(9-44)$ & \\
\hline
\end{tabular}




\begin{tabular}{llccc}
\hline Depersonalization & Yes & $9.54 \pm 3.41$ & $9(5-17)$ & 0.462 \\
& No & $10.13 \pm 3.63$ & $10(5-22)$ & \\
Personal accomplishment & Yes & $29.97 \pm 3.38$ & $29(23-37)$ & 0.316 \\
& No & $28.64 \pm 4.71$ & $29(8-40)$ & \\
Perceived Stress Scale & Yes & $34.79 \pm 4.13$ & $34(26-48)$ & $\mathbf{0 . 0 2 2}$ \\
& No & $32.56 \pm 4.67$ & $33(16-53)$ & \\
\hline
\end{tabular}

Table 3 shows evaluation of Maslach Burnout inventory subscale and Perceived Stress Scale scores according to the voluntary follow-up of COVID-19 disease, status of receiving training and testing status. The scores of the healthcare professionals working voluntarily in COVID-19 service from the Personal accomplishment subscale of the Maslach Burnout Scale were determined to be statistically significantly higher than the employees who did not work voluntarily $(p=0.042)$. Although they did not have any disease symptom, the scores of the healthcare professionals, who tested for COVID-19 disease, from the Emotional burnout and depersonalization subscales of the Maslach Burnout inventory, were found to be statistically significantly higher $(p=0.003$ and $p=0.011$, respectively). Additionally, perceived stress scale scores of these healthcare professionals were statistically significantly higher $(p=0.042)$ (Table3) (Mann-Whitney U test was applied).

Table 3. Evaluation of Maslach Burnout Inventory subscale and Perceived Stress Scale scores according to the voluntary follow-up of COVID-19 disease, status of receiving training and testing status

\begin{tabular}{|c|c|c|c|c|}
\hline & & Mean \pm SD & Median (min- max) & p* \\
\hline \multicolumn{5}{|c|}{$\begin{array}{l}\text { Do you work voluntarily in the service where COVID-19 } \\
\text { patients are followed? }\end{array}$} \\
\hline \multirow[t]{2}{*}{ Emotional burnout } & Yes & $23.79 \pm 8.11$ & $24(9-43)$ & 0.712 \\
\hline & No & $24.14 \pm 7.86$ & $24(9-44)$ & \\
\hline \multirow[t]{2}{*}{ Depersonalization } & Yes & $10.19 \pm 3.72$ & $10(5-22)$ & 0.708 \\
\hline & No & $10.00 \pm 3.54$ & $10(5-21)$ & \\
\hline \multirow[t]{2}{*}{ Personal accomplishment } & Yes & $29.10 \pm 4.92$ & $30(8-38)$ & 0.042 \\
\hline & No & $28.43 \pm 4.36$ & $28(18-40)$ & \\
\hline \multirow[t]{2}{*}{ Perceived Stress Scale } & Yes & $33.37 \pm 4.76$ & $34(18-53)$ & 0.071 \\
\hline & No & $33.37 \pm 4.54$ & $32.5(16-43)$ & \\
\hline \multicolumn{5}{|c|}{ Have you received training on COVID-19 disease? } \\
\hline \multirow[t]{2}{*}{ Emotional burnout } & Yes & $24.12 \pm 8.22$ & $24(9-44)$ & 0.647 \\
\hline & No & $23.52 \pm 7.02$ & $24(9-44)$ & \\
\hline \multirow{2}{*}{ Depersonalization } & Yes & $10.19 \pm 3.69$ & $10(5-22)$ & 0.445 \\
\hline & No & $9.00 \pm 3.33$ & $9(5-17)$ & \\
\hline \multirow[t]{2}{*}{ Personal accomplishment } & Yes & $28.85 \pm 4.54$ & $29(8-40)$ & 0.147 \\
\hline & No & $28.29 \pm 4.89$ & $28(19-39)$ & \\
\hline \multirow{2}{*}{ Perceived Stress Scale } & Yes & $33.00 \pm 4.43$ & $33(18-53)$ & 0.350 \\
\hline & No & $31.18 \pm 5.34$ & $33(16-42)$ & \\
\hline \multicolumn{5}{|c|}{ Have you been tested for COVID-19 disease } \\
\hline \multirow[t]{2}{*}{ Emotional burnout } & Yes & $25.59 \pm 7.79$ & $25(9-44)$ & 0.003 \\
\hline & No & $22.9 \pm 7.91$ & $23(9-44)$ & \\
\hline \multirow[t]{2}{*}{ Depersonalization } & Yes & $10.75 \pm 3.69$ & $10(5-22)$ & 0.011 \\
\hline & No & $9.65 \pm 3.51$ & $9(5-20)$ & \\
\hline \multirow[t]{2}{*}{ Personal accomplishment } & Yes & $28.02 \pm 4.94$ & $28(8-39)$ & 0.085 \\
\hline & No & $29.19 \pm 4.35$ & $29(18-40)$ & \\
\hline \multirow[t]{2}{*}{ Perceived Stress Scale } & Yes & $33.42 \pm 5.16$ & $34(18-53)$ & 0.041 \\
\hline & No & $33.28 \pm 4.29$ & $33(16-42)$ & \\
\hline
\end{tabular}

\section{Discussion}

Among the conditions causing stress in healthcare professionals, excessive workload, insufficient resting times, insufficient support among employees and social relations and some personal characteristics are shown as reasons. ${ }^{16}$ During COVID-19 pandemic period, healthcare professionals have to work at an intense pace and under the risk of transmitting infection. During this process, healthcare professionals have faced many situations that would increase their stress and burnout levels. In the literature, it was determined 
that healthcare workers have a high level of stress in many different countries during the COViD-19 pandemic. ${ }^{17-21}$

Burnout is a serious consequence of ongoing stress that develops when the expectations at work and personal capacities are out of balance. ${ }^{16,22}$ Emotional burnout, the increasing mental distances with the job done by a person (depersonalization) and feeling of decreasing Personal accomplishment are considered as the characteristic components of burnout. ${ }^{22}$ Burnout is frequently seen among the occupational groups working in direct contact with people and it is a known fact that it is common among healthcare professionals. ${ }^{16}$ While nurses provide care to the patients, they present a significant amount of emotional labour in addition to their physical and mental effort. ${ }^{23}$ Nursing is stressful and emotionally demanding with patient cares requiring a lot of effort, limited time and over workload. Besides, the business resources are often insufficient to cope with these demands effectively. ${ }^{24-25}$ Therefore, nurses are particularly susceptible to burnout. In two European epidemiological studies, it was reported that burnout affected approximately $25 \%$ of all nurses. ${ }^{26}$ In the literature, it was determined that the occupational group having the highest burnout level among healthcare professionals was nursing. ${ }^{12-13}$ Also during the COViD-19 pandemic, a study showed that participants who were nurses in their profession were 8 times more likely to have perceived stress on COVID-19 as compared to respondents who were doctors. ${ }^{21}$ It was revealed in the present study that working in COVID-19 pandemic also caused emotional burnout in nurses as well as factors such as excessive workload, increased responsibility, and insufficient self-care which were the strongest determinants of emotional burnout. ${ }^{25}$ Additionally, in their study, Helvaci et al., found that the burnout level of doctors was higher than other healthcare professionals. ${ }^{9}$ A systematic review of 182 studies in the literature reported a general prevalence of burnout of $67 \%$ among physicians. Depersonalization was determined at $68.1 \%$ frequency. ${ }^{27}$ In the present study, considering the workload, stress factors and responsibilities taken by health technicians who were not responsible for the primary care of the patient, depersonalization was seen less.

Kaya et al., found that emotional burnout and stress levels of female healthcare professionals working in the primary care were higher compared to men. ${ }^{10}$ In a study including eight occupational groups including professionals providing human services, more burnout was observed in women. ${ }^{28}$ In a study conducted in colleges including nursing schools in China, female students received higher scores about emotional burnout compared to male students. ${ }^{29}$ The similar result that was also found in the present study can be explained by the fact that while women are expected to suppress their emotions, men are allowed to release negative emotions, especially under heavy working conditions and stress.

Stress scale scores of healthcare professionals having a chronic disease were found to be higher compared to those without any disease. It is known that the presence of a chronic disease in COVID-19 infection negatively affects the prognosis. ${ }^{1}$ Especially, hypertension, diabetes mellitus, chronic obstructive pulmonary disease and malignancy have been found to increase the death risk. ${ }^{30-31}$ In a study evaluating the perceived stress level in elderly patients having multiple morbidity, it was recorded that there was a linear increase in the perceived stress levels along with the increasing number of chronic disease. ${ }^{32}$ Considering the high health costs associated with chronic diseases, low quality of life and thus increasing mortality, the perceived stress level increased linearly. ${ }^{32-33}$ It is believed that the COVID-19 transmission risk and more severe course of the infection in the presence of a chronic disease may have an effect on high stress levels in healthcare professionals.

It was determined that the emotional burnout, depersonalization, and stress levels of the healthcare professionals, giving test from the respiratory tract samples without COVID-19 infection symptoms, were higher as expected. Higher emotional burnout and depersonalization were found in the employees dealing 
with patients with acquired immune deficiency syndrome (AIDS) while they were shown to feel high personal accomplishment. ${ }^{34}$ In the healthcare professionals dealing with the same disease, high burnout level, higher anxiety, stress and stigma levels were found. ${ }^{35} \mathrm{~A}$ similar result observed in the present study is the result of the anxiety of being infected. Various studies on the healthcare professionals showed that both situational factors (for example, professional role, organization) and demographic factors (for example, age, marital status, education) can contribute to burnout. ${ }^{36-37}$ In the present study, when the marital status, having children status, people living with and receiving training about COVID-19 disease were considered, they were seen not to affect emotional burnout, depersonalization, personal accomplishment or stress levels. Since many healthcare professionals have preferred to live alone during pandemic period apart from their home and the people they live with, it is believed that these demographic characteristics do not affect their burnout and stress levels.

The stress variables causing burnout are still being discussed. ${ }^{36-37}$ It has been shown that there is a correlation between the excessive workload, uncertainty of job description, conflict between professional groups, emotional burnout and depersonalization. However, personal accomplishment was not found to have an effect on burnout. ${ }^{36,38}$ It was concluded in the present study that working voluntarily in pandemic services was effective in the high personal accomplishment feelings of healthcare professionals.

The literature suggests that, it is obligatory to discover those factors that increase job stress in health institutions, and to discover appropriate mechanisms to reduce this stress. ${ }^{20}$ it was recommended that greater protection gear supplies, on-going monitoring and provision of psychological support, strong family support may also increase healthcare professionals's resilience to stress and psychological symptoms during a public health emergency. ${ }^{19}$

\section{Conclusion and Recommendations}

During the COVID-19 pandemic, the workload of the healthcare professionals increased even more, since they are in direct contact with COVID patients, their risks of being infected increased and they had a difficult process both physically and mentally. It was found as a result of the present study that their stress and burnout levels were also high in this period. It is important to measure the burnout among healthcare professionals because their well-being has effects on the stability of the health workforce and the quality of care provided.

In this period, reducing the working hours of the employees, regulating the working environment to minimize the nosocomial infection, providing adequate protective equipment, using properly protective equipment, providing trainings about the transmission and protection methods, providing social and psychological support to healthcare professionals in need will be important intervention measures in order to reduce professional stress and prevent burnout.

When it was considered that the perceived stress and chronic diseases are collectively associated with worse health outcomes, taking sufficient protective measures and not allowing those with chronic disease to work in COVID-19 services if necessary should be planned as measures reducing the stress.

Similar studies conducted on healthcare professionals during pandemic period are not available yet in the literature. This is thought to increase the importance of this study.

\section{Acknowledgement}

The authors report no actual or potential conflicts of interest. 


\section{Ethical Approval}

Ethics Committee of Ataturk University Faculty of Medicine (28.05.2020/ B.30.2.ATA.0.01.00/292). Ministry of Health COVID-19 Scientific Research Evaluation Commission (11.05.2020)

\section{Author contributions}

Hatice Yağcl: Idea/Concept, Design, Data Collection and Processing, Literature Review, Writing the Article, References and Fundings.

Nuray Dayapoğlu: Idea/Concept, Control/Supervision, Data Collection and Processing, Critical Review. Ömer Karaşahin: Idea/Concept, Design, Control/Supervision, Data Collection and Processing, Analysis and Interpretation, Literature Review, Writing the Article, Critical Review.

\section{References}

1. Zheng Z, et al. Risk factors of critical \& mortal COVID-19 cases: A systematic literature review and meta-analysis. Journal of Infection 2020;81(2): 16-25.

2. Chan JF, et al. A familial cluster of pneumonia associated with the 2019 novel coronavirus indicating person-to-person transmission: a study of a family cluster. Lancet 2020;395: 514-523.

3. Andersen KG, et al. The proximal origin of SARS-CoV-2. Nat Med 2020;26(4): 450-452.

4. Lu R, et al. Genomic characterisation and epidemiology of 2019 novel coronavirus: implications for virus origins and receptor binding. The Lancet 2020; 395: 565-574.

5. Wu Z, McGoogan JM. Characteristics of and Important Lessons From the Coronavirus Disease 2019 (COVID-19) Outbreak in China: Summary of a Report of 72314 Cases From the Chinese Center for Disease Control and Prevention. JAMA 2020;323(13):1239-1242.

6. Assessment of risk factors for coronavirus disease 2019 (COVID-19) in health workers: protocol for a case-control study. [accessed 5 June 2020]. Available from: https://www.who.int/emergencies/diseases/novel-coronavirus2019?gclid=CjwKCAjwsO_4BRBBEiwAyagRTUDY5etw3tkiULst6EERHOM-5Ih62rTBnh1eMH-R_tdPk4aEYwy_1hoCxDQQAvD_BwE.

7. TC. Sağlık Bakanlığı, Covid-19 Rehberi. 2020. [accessed 5 June 2020]. Available from:

https://covid19bilgi.saglik.gov.tr/depo/rehberler/COVID-19_Rehberi.pdf?type=file

8. Tekir Ö, et al. Examining Health Workers' Burnout, Job Satisfaction Levels and Life Satisfaction. Kırıkkale Üniversitesi Tıp Fakültesi Dergisi 2016; 18(2): 51-63.

9. Helvaci I, Turhan M. The Examination of Burnout Levels: A Study on Healthcare Staff Working in Silifke. İşletme ve iktisat Çalışmaları Dergisi 2013; 1(4): 58-68.

10. Kaya M, et al. The Burnout Condition of Primary Health Care Personnel. TSK Koruyucu Hekimlik Bülteni 2007; 6(5): 357-363.

11. Taycan $\mathrm{O}$, et al. Relation between sociodemographic characteristics depression and burnout levels of nurse working in university hospital. Anadolu Psikiyatri Dergisi 2006; 7(2): 100-108.

12. Çimen M, Ergin C. A. Survey on burnoutlevels of Turkısh armed forces health personnel. Gülhane Tıp Dergisi 2001; 43(2): 169176.

13. Alacacioglu A, et al. Burnout in nurses and physicians working at an oncology department. Psycho-Oncology: Journal of the Psychological, Social and Behavioral Dimensions of Cancer 2009; 18(5): 543-548.

14. Ergin, C. Doktor ve hemşirelerde tükenmişlik ve Maslach Tükenmişlik Ölçeğinin uyarlanması. VII. Ulusal Psikoloji Kongresi; 1992; Sep 22;Türkiye. Ankara, 1992.

15. Eskin M, et al. Algılanan Stres Ölçeğinin Türkçeye uyarlanması: Güvenirlik ve geçerlik analizi. New/Yeni Symposium Journal 2013; 51(3): 132-140.

16. Ersoy F, Yıldırım C, Edirne T. Tükenmişlik (staff burnout) sendromu. Sürekli Tıp Eğitimi Dergisi 2001; 10(2): 46-47.

17. Pedrozo-Pupo J. et al. Perceived stress associated with COVID-19 epidemic in Colombia: an online survey. Cadernos de saude publica 2020; 36(5): e00090520.

18. Besirli A. et al. The Relationship between Anxiety and Depression Levels with Perceived Stress and Coping Strategies in Health Care Workers during the COVID-19 Pandemic. The Medical Bulletin of Sisli Etfal Hospital 2021; 55 (1): 1-11.

19. Du J. et al. Psychological symptoms among frontline healthcare workers during COVID-19 outbreak in Wuhan. General hospital psychiatry 2020; 67:144-145.

20. Abbas S. et al. Encountering Covid-19 and perceived stress and the role of a health climate among medical workers. Current Psychology 2021;23: 1-14.

21. Chekole YA. et al. Perceived Stress and Its Associated Factors during COVID-19 among Healthcare Providers in Ethiopia: A CrossSectional Study. Advances in Public Health 2020: 5036861. Doi: 10.1155/2020/5036861 
22. Maslach C, Jackson SE, Leiter MP, Schaufeli WB, Schwab RL. Maslach burnout inventory. 3rd ed. California:Palo Alto; 1986. pp:3463-3464.

23. Altuntaş S, Altun Öş. The relationship between emotional labor behaviors and burnout levels of nurses. Journal of Health and Nursing Management 2015; 2(1): 37-43.

24. Schaufeli WB, Keijsers GJ, Miranda DR. Burnout, technology use, and ICU performance. In Sauter SL, Murphy LR, editors. Organizational risk factors for job stress. Washington; 1995.pp:259-271.

25. Wu S, et al. Relationship between burnout and occupational stress among nurses in China. Journal of Advanced Nursing 2007; 59(3): 233-239.

26. Lewis D, Robinson J. ICU nurses' coping measures: response to work-related stressors. Critical Care Nurse 1992; $12(2): 18 .$.

27. Rotenstein LS, et al. Prevalence of burnout among physicians: a systematic review. JAMA 2018; 320: 1131-1150.

28. Bakker AB, Demerouti E, Schaufeli WB. Validation of the Maslach burnout inventory-general survey: an internet study. Anxiety, Stress \& Coping 2002; 15: 245-260.

29. Hu Q, Schaufeli WB. The factorial validity of the Maslach burnout inventory-student survey in China. Psychological Reports 2009; 105: 394-408.

30. Guan WJ, et al. Comorbidity and its impact on 1590 patients with Covid-19 in China: A Nationwide Analysis. European Respiratory Journal 2020; 55(5):1-14.

31. Lippi G, Wong J, Henry BM. Hypertension and its severity or mortality in Coronavirus Disease 2019 (COVID-19): a pooled analysis. Pol Arch Intern Med 2020; 130: 304-309.

32. Stubbs B, et al. Multimorbidity and perceived stress: a population-based cross-sectional study among older adults across six low-and middle-income countries. Maturitas 2018; 107: 84-91.

33. Prior A, et al. The association between perceived stress and mortality among people with multimorbidity: a prospective population-based cohort study. American Journal of Epidemiology 2016; 184: 199-210.

34. Oktay JS. Burnout in hospital social workers who work with AIDS patients. Social Work 1992; 37: 432-439.

35. Bennett L, Kelaher M, Ross M. Quality of life in health care professionals: Burnout and its associated factors in HIV/AIDS related care. Psychology \& Health 1994; 9: 273-283.

36. Peiró JM, et al. Does role stress predict burnout over time among health care professionals? Psychology \& Health 2001; 16: 511525.

37. Schaufeli WB, Greenglass ER. Introduction to special issue on burnout and health. Psychology \& Health 2001; 16: 501-510.

38. Dorz S, et al. Predicting burnout among HIV/AIDS and oncology health care workers. Psychology and health 2003; 18: 677-684. 